\title{
THE ROLE OF THE PRIVATE SECTOR IN RESOLUTION FOR BANKS
}

\author{
NICOLA RUCCIA ${ }^{1}$
}

ruccia.nicola@libero.i†

\author{
Cómo citar/Citation \\ Ruccia, N. (2017). \\ The role of the private sector in resolution for banks. \\ Revista de Derecho Comunitario Europeo, 57, 615-640. \\ doi: https://doi.org/10.18042/cepc/rdce.57.06
}

\begin{abstract}
The recent financial crisis in the Euro area has shown the close and negative relationship between the balance sheets of some Member States and their banks. The $\mathrm{EU}$, in order to interpose in such a relationship, has taken several measures. One of the most important is the institution of a resolution regime for banks which provides a specific role for the private sector. This paper is aimed at analysing the EU legal framework on the matter. Firstly, it grasps the original setting of the question with the purpose of understanding why sovereign risk and bank risk are strictly linked. Successively, it examines the EU rules defining resolution for banks. Within this ambit, it focuses on the bail-in and the limits on its application as well as on the Single Resolution Fund. Furthermore, it evaluates the role at issue in the light of the right to property. Finally, it analyses the assessment of the Court of Justice on whether, and to what extent, the involvement of the private sector in resolution for banks is lawful.
\end{abstract}

\section{Keywords}

Financial crisis; euro; banking union; resolution; bail-in; right to property.

1 Contract Professor of European Law, Polytechnic of Bari. The author wishes to express his gratitude to Ivan Ingravallo for discussions and comments on earlier drafts of this text. The usual disclaimer applies. 


\section{EL PAPEL DEL SECTOR PRIVADO EN LA RESOLUCIÓN DE LOS BANCOS}

\section{Resumen}

La reciente crisis financiera en la Zona Euro ha puesto de manifiesto la estrecha y negativa relación entre el presupuesto de algunos Estados Miembros y el de sus bancos. La Unión Europea — con el objeto de interponerse en esta relación-ha adoptado diferentes medidas. Una de las más importantes consiste en la creación de un régimen de resolución de bancos en graves dificultades, que asigna un papel especifico al sector privado. Este trabajo pretende analizar el marco jurídico de la UE en esta materia. En primer lugar, aborda el problema inicial para comprender por qué el riesgo soberano y el riesgo bancario están estrechamente vinculados. En segundo lugar, se examinan las normas de derecho de la UE que definen la resolución de los bancos en graves dificultades. A este respecto, se analizan el principio de recapitalización interna (bail-in) y los límites de su aplicación, y el Fondo de Resolución Única. Además, se considera la resolución de los bancos desde la perspectiva del derecho de propiedad. Por último, se analiza la posición del TJUE sobre la cuestión con el objeto de comprender, si y en qué medida, la participación del sector privado en la resolución de los bancos es conforme al derecho de la Unión europea.

\section{Palabras clave}

Crisis financiera; euro; unión bancaria; resolución; recapitalización interna; derecho de propiedad.

\section{LE ROLE DU SECTEUR PRIVÉ DANS LA RÉSOLUTION DES BANQUES}

\section{Résumé}

La récente crise financière dans la zone euro a mis en évidence l'étroite et négative relation entre les bilans de certains États Membres et ceux de leurs banques. L'UE, afin de s'interposer dans cette relation, a adopté plusieures mesures. Parmi celles-ci, une des plus importantes est représentée par l'institution d'un régime de résolution des banques défaillantes qui assigne un rôle spécifique au secteur privé. Cet art. vise à analyser le cadre juridique européen en la matière. Tout d'abord, il saisit le problème initial, afin de comprendre pourquoi le risque souverain et le risque bancaire sont strictement liés. Ensuite, il examine les normes de droit de l'UE définissant la résolution des banques défaillantes. A cet égard, il analyse le principe de renflouement interne (bail-in) ainsi que les limites de son application et le Fonds de Résolution Unique. En outre, il évalue la résolution des banques à la lumière du droit de propriété. Enfin, il analyse l'appréciation de la Cour de justice sur la question afin de comprendre si, et dans quelle mesure, la participation du secteur privé dans la résolution des banques défaillantes est conforme au droit de l'UE.

\section{Mots cles}

Crise financière; euro; union bancaire; résolution; renflouement interne; droit de propriété. 


\section{SUMMARY}

I. SOVEREIGN RISK AND BANK RISK. II. RESOLUTION FOR BANKS. III. BAIL-IN. IV. LIMITS TO THE APPLICATION OF BAIL-IN. V. THE SINGLE RESOLUTION FUND. VI. THE PROTECTION OF THE RIGHT TO PROPERTY IN RESOLUTION FOR BANKS. VII. THE COURT'S APPROACH. VIII. CONCLUSION.

\section{SOVEREIGN RISK AND BANK RISK}

The recent financial crisis in the Euro area has made it clear that the internal market was not equipped with the necessary tools to cope with its asymmetric shocks ${ }^{2}$. These are particular events that affect, under the economic profile, one or more regions of a specific area in a different way than the others ${ }^{3}$. They even led many to question the confidence in the Euro and, in some circumstances, in the entire process of European integration ${ }^{4}$.

2 Armin STEINBACH, Economic Policy Coordination in the Euro Area, Routledge, Oxon-New York, 2014, p. 9; André SAPIR, «The Eurozone needs less heterogeneity», Vox CEPR's Policy Portal, 12 February 2016, available at: http://voxeu.org/article/eurozone-needs-less-heterogeneity.

3 J. K. DREYER and P. A. SCHMID, «Fiscal federalism in monetary unions: hypothetical fiscal transfers within the Euro-zone», International Review of Applied Economics, vol. 29, no. 2, 2015, pp. 506-532.

4 See Niamh MOLONEY, «EU Financial Market Regulation After the Global Financial Crisis: More Europe or More Risks?», Common Market Law Review, vol. 47, 2010, pp. 1317-1383; Jean-Victor LOUIS, "Les réponses à la crise», Cahiers de droit européen, vol. 47, no. 2, 2011, pp. 353-367; Frédéric ALLEMAND and Francesco MARTUCCI, "La nouvelle gouvernance économique européenne», (I) and (II), Cahiers de droit européen, vol. 1/2012, pp. 17-99, 2/2012, pp. 409-457; Edoardo CHITI and Pedro Gustavo TEIXEIRA, "The Constitutional Implications of the European Responses to the Financial and Public Debt Crisis", Common Market Law Review, vol. 50, no. 3, 2013, pp. 683-708; Catherine PRIETO, «Union bancaire, ou l'art de se payer de mots», Revue trimestrielle de droit européen, vol. 50, no. 1, 2014, pp. 3-6. 
The financial crisis first appeared in the United States following the insolvency of subprime mortgage holders. These are loans at high interest rates to individuals without adequate repayment guarantees whose risks have been transferred, through the process of securitization, to international financial markets and, therefore, also to the Euro area one ${ }^{5}$.

In the latter, its financially and fiscally weakest Member States -i.e. Portugal, Ireland, Italy, Greece and Spain (PIIGS) - have been greatly affected by the crisis. With reference to their government bonds, private investors have, initially, avoided employing new resources and, subsequently, started to withdraw those previously immobilised, pushing up yields and increasing the riskiness of the underlying transactions. Conversely, in the financially and fiscally strongest Member States -i.e. Germany, Finland and The Netherlands- interest rates of government bonds, modest in themselves before the crisis, have declined due to the high level of their security and, thus, of their demand. Ultimately, sovereign yields in the Euro area were broadly diversified, as evidenced by the levels of the interest rate spreads ${ }^{6}$. These show the differences between government bond interest rates of two Member States, one of which is generally — due to its importance in the EU economic system- Germany ${ }^{7}$.

Competitiveness of debt securities on domestic financial markets of the weakest Member States required that private bond yields would be adapted and, in many circumstances, equated to the government ones. As a result, in them the granting of loans to the private traders - banks and, therefore, enterprises - has been carried out at higher interest rates than those imposed elsewhere. Their products have been exported at higher prices to pay those higher interest rates — since Euro area Member States have no autonomous impact on the foreign exchange market - with an almost negative effect on the balance of payments.

5 Yesim M. ATAMER, "Duty of Responsible Lending: Should the European Union Take Action?», in Stefan GRUNDMANN and Yesim M. ATAMER (eds.), Financial Services, Financial Crisis and General European Contract Law, Kluwer Law International, Alphen aan den Rijn, 2011, pp. 179-202, p. 182.

6 ECB, Harmonised long-term interest rates for convergence assessment purposes, available at: http://sdw.ecb.europa.eu/browseTable.do?node=bbn4864.

7 Elisabeth HOLOUBEK, The Eurobonds Guide: Will They Help Us Out of the Economic Crisis?, Anchor Academic Publishing, Hamburg, 2013, p. 38. 
This mechanism led, substantially, to a variegated level of the value of the Euro in the Member States and not to a uniform one throughout the Economic and Monetary Union considered as a whole. Where the crisis was deeper, the common currency was implicitly devalued in the financial market and revalued in the exchange rate market, with totally distorting effects.

The parallel trend of government and private bond yields reflects the close and negative relationship between sovereign risk and bank risk. The former refers to the danger of government default on a loan made to a Member State or guaranteed by it. The latter is the uncertainty about future cash flow of a bank, the probability of loss or revenue shortfall — compared with the planned - of its resources as a result of certain financial transactions. It can lead to the recourse to central bank or government liquidity ${ }^{8}$. In the financially and fiscally weakest Member States, public intervention on troubled banks has generated an increase of the level of sovereign debts - which involved the above-mentioned rise in government and private yields - while the purchase by banks of bonds of Member States with large deficits has increased their risks — requiring them to pay higher interest rates and making it more difficult to raise funds - and undermined their financial stability ${ }^{9}$. This spiral, due to a propagation effect, has taken on a cross-border dimension and seemed to have no end.

The EU, to interpose in such a spiral, has launched an action characterised by two parallel aims of financial stability —one regarding the Member States and the other concerning their credit institutions - both converging to the overall stability of the financial system in the internal market.

To this end, it intervened with several measures. With reference to the sovereign risk they include, in a not exhaustive list: the European Financial

8 Yener ALTUNBAS, Simone MANGANELLI and David MARQUES-IBANEZ, "Bank Risk During the Financial Crisis. Do Business Models Matter?», ECB Working Papers, no. 1394, 2011, available at: https:/www.ecb.europa.eu/pub/pdf/scpwps/ecbwp1394.pdf.

9 Franklin ALLEN and Elena CARLETTI, «Systemic Risk and Macroprudential Regulation", in Hans-W. MICKLITZ and Takis TRIDIMAS (eds.), Risk and EU Law, Edward Elgar Publishing, Cheltenham-Northampton, 2015, pp. 197-219, p. 208. 
Stabilisation Mechanism (EFSM) ${ }^{10}$, the Six-Pack ${ }^{11}$, the Two-Pack ${ }^{12}$, the European Stability Mechanism (ESM) ${ }^{13}$ and the Fiscal Compact ${ }^{14}$. These measures have led to a new EU economic governance ${ }^{15}$.

With regard to the bank risk, the most relevant are the Bank Recovery and Resolution Directive (BRRD) ${ }^{16}$ and the institution of the Banking Union.

10 Council Regulation (EU) no. 407/2010 of 11 May 2010 establishing a European financial stabilisation mechanism (OJ L 118, 12.5.2010, p. 1).

11 Regulation (EU) no. 1173/2011 of the European Parliament and of the Council of 16 November 2011 on the effective enforcement of budgetary surveillance in the euro area (OJ L 306, 23.11.2011, p. 1); Regulation (EU) no. 1174/2011 of the European Parliament and of the Council of 16 November 2011 on enforcement measures to correct excessive macroeconomic imbalances in the euro area (ibid., p. 8); Regulation (EU) no. 1175/2011 of the European Parliament and of the Council of 16 November 2011 amending Council Regulation (EC) no. 1466/97 on the strengthening of the surveillance of budgetary positions and the surveillance and coordination of economic policies (ibid., p. 12); Regulation (EU) no. 1176/2011 of the European Parliament and of the Council of 16 November 2011 on the prevention and correction of macroeconomic imbalances (ibid., p. 25); Council Regulation (EU) no. 1177/2011 of 8 November 2011 amending Regulation (EC) no. 1467/97 on speeding up and clarifying the implementation of the excessive deficit procedure (ibid., p. 33) and Council Directive 2011/85/EU of 8 November 2011 on requirements for budgetary frameworks of the Member States (ibid., p. 41).

12 Regulation (EU) no. 472/2013 of the European Parliament and of the Council of 21 May 2013 on the strengthening of economic and budgetary surveillance of Member States in the euro area experiencing or threatened with serious difficulties with respect to their financial stability (OJ L 140, 27.5.2013, p. 1) and Regulation (EU) no. 473/2013 of the European Parliament and of the Council of 21 May 2013 on common provisions for monitoring and assessing draft budgetary plans and ensuring the correction of excessive deficit of the Member States in the euro area (ibid., p. 11). Signed on 2 February 2012

14 Signed on 2 March 2012.

15 Manuel LÓPEZ ESCUDERO, «La nueva gobernanza económica de la Unión Europea: ¿̨una auténtica unión económica en formación?», Revista de Derecho Comunitario Europeo, no. 50, 2015, pp. 361-433.

16 Directive 2014/59/EU of the European Parliament and of the Council of 15 May 2014 establishing a framework for the recovery and resolution of credit institutions and investment firms and amending Council Directive 82/891/EEC, and Directives 2001/24/EC, 2002/47/EC, 2004/25/EC, 2005/56/EC, 2007/36/EC, 2011/35/EU, 2012/30/EU and 2013/36/EU, and Regulations (EU) no. 1093/2010 and (EU) no. 648/2012, of the European Parliament and of the Council (BRRD) (OJ L 173, 12.6.2014, p. 190). 
The latter is a highly centralised system composed of three interconnected pillars: the Single Supervisory Mechanism $(\mathrm{SSM})^{17}$, the Single Resolution Mechanism (SRM) — and the related Single Resolution Fund (SRF) ${ }^{18}$ — and the European Deposit Insurance Scheme (EDIS) ${ }^{19}$.

The common ground of these measures is the statement of the principle of burden sharing introduced by the Banking Communication ${ }^{20}$. It is based on the involvement of the private sector - going beyond minimum requirements under State aid rules - before granting any kind of public support, in the resolution of a credit institution. In other words, it provides that a bank - and its capital holders - has to contribute to the restructuring as much as possible with its own resources by absorbing losses with available capital and by paying an adequate remuneration for the eventual State aids. The purpose is to limit distortions of competition in the internal financial market. In this new legal framework, the higher degree of burden sharing is the bail-in of investors and/or creditors of the bank under resolution.

\section{RESOLUTION FOR BANKS}

Resolution for banks has been defined both in the $\mathrm{BRRD}^{21}$ and Regulation num. 806/201422. As stated in art. 31, para. 2, BRRD and art. 14, para. 2, Regulation num. 806/2014, it aims at ensuring the continuity of the critical functions -i.e. the essential financial services - of a bank under financial stress, to maintain the stability of the financial system and to avoid significant adverse effects on

17 Council Regulation (EU) no. 1024/2013 of 15 October 2013 conferring specific tasks on the European Central Bank concerning policies relating to the prudential supervision of credit institutions (OJ L 287, 29.10.2013, p. 63).

18 Regulation (EU) no. 806/2014 of the European Parliament and of the Council of 15 July 2014 establishing uniform rules and a uniform procedure for the resolution of credit institutions and certain investment firms in the framework of a Single Resolution Mechanism and a Single Resolution Fund and amending Regulation (EU) no. 1093/2010 (OJ L 225, 30.7.2014, p. 1).

19 Proposal for a Regulation of the European Parliament and of the Council amending Regulation (EU) no. 806/2014 in order to establish a European Deposit Insurance Scheme, COM (2015) 586 final.

20 Communication from the Commission on the application, from 1 August 2013, of State aid rules to support measures in favour of banks in the context of the financial crisis (Banking Communication) (OJ C 216, 30.7.2013, p. 1).

21 See note 16.

22 See note 18 . 
it, to reduce moral hazard and to protect public funds, both by minimising reliance on extraordinary public financial support and, finally, to protect depositors, investors, client funds and client assets. Basically, it is directed towards planning the management of the bank crisis before it manifests itself in all its gravity.

According to art. 33, BRRD, resolution actions are taken if a bank is failing or is likely to fail and —with regards to timing and other relevant circumstances - there is no realistic prospect that any alternative private sector measures would prevent its failure within a reasonable time-frame. Finally, they must be necessary in the public interest. These actions should minimise the cost of resolution borne by public funds and avoid destruction of value unless necessary to achieve the resolution aims.

Art. 37, para. 3, BRRD and art. 22, para. 2, Regulation num. 806/2014 provide four types of resolution tools: the sale of the business, the establishment of a bridge institution (the s.c. bridge bank), the asset separation (the s.c. bad bank) and the bail-in. The first —as mentioned in art. 38, BRRD and art. 24, Regulation num. 806/2014- is the transfer to a purchaser, on commercial terms and without requiring the consent of shareholders, of the whole or part of the shares or other instruments of ownership or any assets, rights or liabilities of the bank concerned ${ }^{23}$. Conforming to art. 40, BRRD and art. 25 , Regulation num. 806/2014, the second is a temporary tool. It consists in a legal person - controlled by public authorities - created for the purpose of receiving and holding some or all of the shares or other instruments of ownership of the bank involved, or its assets, rights and liabilities with a view to maintaining access to critical functions and selling it when market conditions become appropriate ${ }^{24}$. Pursuant to art. 42, BRRD and art. 26, Regulation num. 806/2014, the third - that can be admitted only in conjunction with another tool, in order to minimise competitive distortion- allows the transfer of impaired assets to an asset management vehicle, with the aim to permit them to be managed and sold over time and to cleanse the balance sheet of the troubled banks ${ }^{25}$. The fourth is provided in art. 43, BRRD and art. 27, Regulation num. 806/2014 and is the most controversial ${ }^{26}$. It assigns the pri-

23 Michael SCHILLIG, «The EU Resolution Toolbox», in Matthias HAENTJENS and Bob WESSELS (eds.), Researching Handbook on Crisis Management in the Banking Sector, Edward Elgar Publishing, Cheltenham-Northampton, 2015, pp. 81-102, p. 91.

Ibid., p. 93.

25 Alexander WELLERDT, Organisation of Banking Regulation, Springer, Hamburg, 2015, p. 70.

26 Niamh MOLONEY, EU Securities and Financial Markets Regulation, $3^{\circ}$ ed., Oxford University Press, Oxford, 2015, p. 423. 
vate sector a specific role in resolution for banks since it uses debt capital as a means of absorbing bank losses in advance of using public funds ${ }^{27}$.

\section{BAIL-IN}

Bail-in is defined —in art. 2, para. 1 (57), BRRD and art. 3, para. 1 (33), Regulation num. 806/2014 - as the mechanism for effecting the exercise of the write-down and conversion powers in relation to liabilities of an entity under resolution. It consents to reduce the claims of unsecured creditors and to transform debt into equity.

According to art. 43, para. 2, BRRD and art. 27, para. 1, Regulation num. 806/2014, this tool is conceived to recapitalise a bank under resolution to the extent necessary to restore its ability to comply with its authorisation conditions and to continue carrying out its activities ${ }^{28}$. Furthermore, it must contribute to sustaining sufficient market confidence in the same bank.

Throughout bail-in, the rescue of a credit institution is done within the banking system, attributing its cost to those private operators who have invested in the institution itself. These investors are considered to be in the most appropriate financial position. In fact, they have the most comprehensive information on the credit risk since they have the most extensive monitoring capabilities and can determine the pricing of the more efficient risk ${ }^{29}$.

Bail-in is focused on the assumption - stated in art. 44, para. 9, BRRD and art. 27, para. 12, Regulation num. 806/2014 - that the losses of a bank should be charged, firstly, to its shareholders and subsequently, according to a special hierarchy, among its creditors. This could minimise the costs of resolution supported by taxpayers, ensuring that interventions concerning systemically important entities are possible without jeopardising financial stability in the Member State concerned and, due to an effect of propagation, in other Member States of the Banking Union. Bail-in should ensure, in other words, that the shareholders and creditors of an entity in financial distress substan-

27 Andreas KOKKINIS, «A Primer on Corporate Governance in Banks and Financial Institutions: Are Banks Special?», in Iris H.-Y. CHIU (ed.), The Law on Corporate Governance in Banks, Edward Elgar Publishing, Cheltenham- Northampton, 2015, pp. 1-41, p. 28.

28 See, Thomas F. HUERTAS, "The Case for Bail-ins», in Andreas DOMBRET and Patrick S. KENADIJAN (eds.), The Bank Recovery and Resolution Directive: Europe's Solution for "Too Big To Fail?», De Gruyter, Berlin-Boston, 2013, pp. 167-188, p. 167.

29 Giancarlo FORESTIERI, «L'Unione bancaria europea e l'impatto sulle banche», Banca Impresa Società, no. 3, 2014, pp. 489-504, p. 496. 
tially sustain its losses, taking on an equally proportionate share of the relative costs. Its aim is to establish, in a definitive manner, the transfer of the risk of investments from the balance sheets of the Member States towards investors and, consequently, the separation of balance sheets of the credit institutions from those of the respective Member States, from which the absence of any link of solidarity in the payment of debts originates. As a result, this instrument should stop the above-mentioned spiral between bank risk and sovereign risk ${ }^{30}$.

Bail-in implies, therefore, a real change in the approach to the payment of banks' losses. The principle of privatization of profits when the balance sheets of banks are active and the socialization of losses, when they occur in insolvencies, does not apply ${ }^{31}$. Thus, this would lead to the elimination of the implicit public guarantee that, under the principle 'too big to fail' - having as its goal to prevent the failure of a large bank since it could compromise the entire banking system or the level of the national public debt - has long protected depositors and bank bondholders ${ }^{32}$.

The main consequence of the application of this tool would be, at least in principle, the annulment of the impact of banks' bailout on the public debts of the respective Member States, since budgetary resources should not be used in order to avoid the negative externalities represented by the wellknown spiral effects.

It can be said that bail-in is also based on the principle of the non-translation of costs in the distribution of responsibilities between banks and Member States, stating that these costs should be borne by those who caused them, thus stimulating a rigorous discipline in the management of credit institutions. Therefore, it will give shareholders and creditors of banks a stronger incentive to monitor the health of the latter during normal circumstances. Furthermore, since art. 34, para. 1 (c), BRRD and art. 15, para. 1 (c), Regulation num. 806/2014, provide for the automatic replacement of management when bail-in is applied, except where its retention results appropriate and necessary for the achievement of the resolution objectives. This would greatly boost the operational efficiency of the management itself. Under this profile, one must observe that bail-in would avoid the s.c. moral hazard practices.

30 Supra, para. 1.

31 Giuseppe BOCCUZZI, «La gestione delle crisi bancarie nel quadro dell'Unione bancaria europea", Bancaria, no. 2, 2015, pp. 1-10, p. 6.

32 Maxim HOHMANN, The Impact of Regulation on Remuneration in Banks. An Analysis of EU, UK and German Law, Anchor Academic Publishing, Hamburg, 2017, p. 32. 
They consist of business statements based on some purposes that are different from those that are typical for a credit institution. They are carried out by the bank administrators for reasons other than those of its clients in the belief of being able to be overcome in the future by the economic support of the respective Member States, whose financial equilibrium would risk being altered by them ${ }^{33}$. As a result, bail-in would ensure that banks bear adequate responsibility for the consequences of their past activities and create appropriate incentives for their future behaviours. In essence, it would prevent them from making questionable decisions that might impact the balance sheets of Member States, irrespective of the level of indebtedness of the latter and, thus, compromising sustainable domestic economic systems.

In other words, anyone who runs a credit institution or participates in its capital or, even, invests in its securities should not manifest heedlessly towards the risk undertaken by it as nor avoid the constant monitoring of its financial soundness and solvency. In our opinion, bail-in has a double impact on the efficiency of banks. On the one hand, it represents an incentive - for their management - for their efficient performances. On the other hand, it is for their shareholders and creditors - a great boost to their oversight under normal market circumstances. Indeed, it would imply that bank management and the investments in them take place, exclusively, throughout financial market rules. In this manner, one should defer to the latter the evaluation of the reliability of credit institutions since their financial operations, whether carried out in the awareness that public funds cannot cope with their eventual negative outcomes or not, should be made with caution. The performance of the financial market, therefore, should affect the behaviour of credit institutions. For those greatly indebted, raising funds could only take place at particularly costly conditions, because of the volatility of their investments. For those less indebted — which offers greater guarantees of solvency - the same raising of funds should take place in less costly conditions. The lower cost of these operations, due to the implicit guarantee of which banks have benefited so far, would be extinct from the risk premium demanded by investors ${ }^{34}$.

At the same time, the latter will be on the front line of facing bank losses, in order to make market discipline more direct and selective. In other words, bail-in brings the structure of the banking system to the rules

33 Ramona IANUS and Massimo F. ORZAN, "Aid Subject to a Discretionary Assessment Under Article 107(3) TFEU», in Herwig C.H. HOFMANN, Claire MICHEAU (eds.), State Aid Law of the European Union, Oxford University Press, Oxford, 2016, pp. 240-307, p. 274.

34 FORESTIERI, op. cit., p. 496. 
of the market economy: enterprises not generating profits cannot operate properly in the market and the effects of their default primarily shift to their shareholders and, secondly, to their creditors, starting with those less guaranteed.

Finally, bail-in tends to restrict, progressively, the freedom of action of credit institutions in the financial market, with the increase of their exposure to the risk of default. The same financial market, therefore, could serve as a self-regulatory mechanism of the risk appetite of banks. However, one must observe that it does not always represent the appropriate deterrent for non-rigorous financial operations. Furthermore, the most indebted credit institutions, due to the probability and level of their potential losses, may find themselves in increasing difficulties in raising funds because of the higher risk premium - and the connected higher interest rate - they should correspond to investors. As a result, the financial market tends to be characterised by heterogeneous pricing levels, those of indebtedness - lowest for solid banks and highest for weak- which may be, in particular circumstances, quite significant. This leads to the s.c. fragmentation of the financial market which refers, in its more general sense, to the differences between the fundamentals -including, firstly, pricing levels - of the latter ${ }^{35}$.

Since one of the variables in determining the impact of bail-in on funding raises is represented by the asset quality of the credit institution involved, it should be concluded that the effects of the write-down or conversion of liabilities on the cost of the same funding raises will be concentrated, for the most part, on the weaker banks increasing the fragmentation at issue ${ }^{36}$.

Under this profile, one can conclude that the expectation of the bail-in to curb fragmentation in the European financial market and to become an instrument of greater sectorial —i.e. banking —integration seems not always to be justified and even capable of leading to results opposite to those expected.

35 European Parliament, Financial market fragmentation in the Euro area: State of play, December 2016, p. 8. For a general overview of the financial market fragmentation see, Luc LAEVEN and Thierry TRESSEL, «Fragmentation of the Financial System», in Charles ENOCH, Luc EVERAERT, Thierry TRESSEL and. Jian-Ping ZHOU (eds.), From Fragmentation to Financial Integration in Europe, IMF Publication Service, Washington, 2014, pp. 139-166, p. 163.

FORESTIERI, op. cit., p. 498. 


\section{LIMITS TO THE APPLICATION OF BAIL-IN}

Not all of the liabilities of a credit institution may be subjected to the application of bail-in. Art. 44, para. 2, BRRD and art. 27, para. 3, Regulation num. 806/2014 provide a list of those mandatorily excluded. The common ground of their exclusion is their protection in normal insolvency proceedings or the need for continuity of business operations ${ }^{37}$. The most important are the covered deposits, whose full protection is a general principle governing resolution affirmed in both acts of secondary law, respectively art. 34, para. 1 (h) and art. 15, para. 1 (h). With reference to the specific reasons for their exclusion one can affirm that their preferred status may facilitate the separation and transfer of critical functions related to them -i.e. deposit taking and current accounts - to a private sector purchaser or a bridge bank ${ }^{38}$. This would allow, as a result, the application of less invasive resolution tools. One must also observe that the deposit guarantee scheme, i.e. the third pillar of the Banking Union ${ }^{39}$, should contribute to financing the resolution plan by absorbing losses of the bank to the extent of the net losses that it would have had to suffer after compensating depositors in normal insolvency proceedings. Without this system, an undue advantage for the holders of covered deposits, over other creditors of the bank to which the resolution authorities would exercise their powers, would be constituted.

Other categories of liabilities are exempted too. For some of them, the aim is to avoid destabilising effects on the financial system, at least in a potential way, that might take place if they are admitted to the bail-in. These are assets or liquidity of customers of a bank —including those held from undertakings of collective investment in the form of transferable securities and alternative investment funds - provided that such customers are protected from the current national bankruptcy law. These are also liabilities arising by virtue of a fiduciary relationship between a credit institution and other financial operators, provided that the latter are protected by national bankruptcy or civil law. For other categories of exempted liabilities, however, the same destabilising effects seem not to be configurable. The most important of them are liabilities arising from a participation in payment systems which

37 Dirk H. BLIESENER, «Legal Problems of Bail-ins under the EU’s Proposed Recovery and Resolution Directive», in DOMBRET and KENADJIAN (eds.), op. cit., pp. 189-228, p. 199.

38 Annemarie van der ZWET, «Crisis Management Tools in the EU: What Do Really Need?», DNB Occasional Studies, 2011, p. 20.

39

Supra, para. 1. 
have a remaining maturity of less than seven days, or liabilities to entities, excluding those that are part of the same group, with an original maturity of less than seven days.

In any case, one can observe that the exclusion of certain liabilities from the application of the bail-in -i.e. the mandatory involvement of the private sector in resolution for banks - actually improves the autonomous and voluntary involvement of the same private sector in the operation at issue. Where resolution plans exclude bail-in in favour of another resolution tool, for example the asset separation, saving only the sound parts of a troubled bank, they leave the bad assets behind in it, increasing the attractiveness of its sound parts for a private sector purchaser. Thus, the preferred option implying the autonomous involvement of the private sector becomes feasible more often. In cases where it can still not be realised, the required level of the involvement at issue will be determined throughout the bail-in.

Even when the bail-in is applied, in exceptional circumstances certain liabilities may be excluded, either partially or completely, from the application of the write-down or conversion powers. This can take place only in four cases, provided in art. 44, para. 3, BRRD and art. 27, para. 5, Regulation num. 806/2014. The first occurs when it is not possible to bail-in those liabilities within a reasonable time notwithstanding the good faith efforts of the relevant national resolution authority. In the second, the exclusion is necessary and proportionate to achieve the continuity of critical functions and core business lines in a manner that maintains the ability of the bank involved to continue key operations. In the third, the exclusion is necessary and proportionate to avoid giving rise to widespread contagion, in particular as regards eligible deposits held by natural persons and micro, small and medium-sized enterprises, which would severely disrupt the functioning of financial markets, in a manner that could cause a serious disturbance to the economy of a Member State or of the EU as a whole. In the last one, the application of the bail-in tool to those liabilities would cause a destruction in value such that the losses borne by other creditors would be higher than if those liabilities were excluded from bail-in.

The exclusion at issue reflects the need to address practical obstacles to the strict application of bail-in and to avoid its undesired detrimental effects. The aim is to effectively safeguard the principle of proportionality laid down in art. $5 \mathrm{TEU}^{40}$. However, it represents a modification of the ranking of credits

40 Karl-Philipp WOJCIK, «Bail-in in the Banking Union», Common Market Law Review, vol. 53, no. 1, 2016, pp. 91-138, p. 109. 
under national insolvency laws where insured deposits and short-term credits are on the same level of unsecured credits ${ }^{41}$.

\section{THE SINGLE RESOLUTION FUND}

The SRF —established in art. 67, Regulation num. 806/2014- is a paramount element for the involvement of the private sector in resolution of credit institutions. Particularly, it has been provided for the purpose of ensuring the efficient implementation of resolution tools and powers and for the equalisation across countries of banks' bailout prospects. Without it, investors would persist to determine borrowing conditions according to the place of establishment of the banks rather than to their creditworthiness.

The SRF is pre-funded with bank contributions, which are raised at the national level but pooled at EU level. These contributions from individual banks must be raised ex-ante, in order to attain a determined target level of pre-funding, able to guarantee resources available under any circumstances and to avoid destabilising effects of an ex-post levy on other banks. According to art. 69, Regulation num. 806/2014, its accessible financial means will reach at least $1 \%$ of the amount of covered deposits of all credit institutions authorised in all of the participating Member States. This level must be reached gradually over a period of eight years which could be extended, by up to four more years, if it has made cumulative disbursements of more than $0.5 \%$ of covered deposits. Thereafter, if its financial resources fall below the target, they must be refilled through supplementary contributions. The latter, as stated in art. 71, para. 1, Regulation num. 806/2014, can also be imposed on an extraordinary basis and up to a limit ex post, if the pre-funded resources are insufficient to cover the cost of resolution actions.

Pursuant to art. 76, Regulation num. 806/2014, the SRF's resources must be used exclusively for the implementation of resolution tools and resolution powers. They can provide extended short-term funding to a failed bank or a bridge entity and guarantees to potential purchasers of a failed bank or injection of capital in a bridge entity, but they cannot be used directly to absorb losses of the failed bank or to recapitalise it. As a result, the SRF cannot replace the bail-in of shareholders and/or creditors of a bank under resolution. Finally, any decisions on the use of the resources must be taken by the Single Resolution Board (SRB) of the SRM, which is responsible for its administra-

41 Emilios AVGOULEAS, Governance of Global Financial Markets: The Law, the Economics, the Politics, Cambridge University Press, Cambridge, 2012, p. 417. 
tion. Within this ambit, it must be noted that, while the resources are drawn from the private banking sector - not from the taxpayer- any resolution action involving the SRF, as established in art. 18, paras 9 e 19, Regulation num. 806/2014, needs the approval of the European Commission, just as if it were a type of state $\mathrm{aid}^{42}$. In other words, the private financial external support to a bank under resolution is admitted, exclusively, according to a decision normally taken, at EU level, to grant public funds. As a result, it appears a form of conditionality concerning, for example, the recipient bank, including burden-sharing requirements, restrictions on the payment of dividends and/ or on capital management transactions and prohibitions on group expansion and/or aggressive commercial strategies.

The SRF can act where the application of bail-in —under conditions set out in art. 27, para. 5, Regulation num. 806/2014- is excluded or partially excluded for certain liabilities ${ }^{43}$. Before its use, however, the level of write-down or conversion of other eligible liabilities may be increased to take account of such exclusions subject to the "no creditor worse off principle» being respected ${ }^{44}$. Only if the losses cannot be passed to other creditors, may it make a contribution to the bank under resolution provided that losses totalling not less than $8 \%$ of total liabilities including own funds have already been absorbed. This amount is considered as consistent with the level of losses incurred by investors during the recent financial crisis ${ }^{45}$. Furthermore, such contribution must not exceed $5 \%$ of total liabilities of the bank ${ }^{46}$. Thus, it should be considered a private bail-out, accessible only after the use of the resources of non-guaranteed shareholders and depositors. In conclusion, even if bail-in is not fully applied, the private sector -investors, shareholders and the general banking system through the SRF- must finance the resolution plan of a bank with, at least, $13 \%$ of its total liabilities. After this threshold, it is possible to exploit public funds.

While the SRF has been established within the EU, arrangements regarding the transfer to and the mutualisation of contributions to it have been defined, according to arts. 1 and 77, Regulation num. 806/2014, in an international agreement (IGA) signed by the Member States participating in the

42 Christos HADJIEMMANUIL, "Bank Resolution Financing in the Banking Union», LSE Law, Society and Economy Working Papers, no. 6, 2015, available at: https:/www. lse.ac.uk/collections/law/wps/WPS2015-06_Hadjiemmanuil.pdf, 28.

43 Supra, para. 4.

44 Infra, para. 6.

45 Supra, para. 1.

46 Each percentage must be calculated at the time of the beginning of the resolution plan. 
$\mathrm{SSM}^{47}$. This agreement, as stated in its art. 11, para. 2, would enter into force on the first day of the second month following deposit of ratification by Member States that represent $90 \%$ of the aggregate of the weighted votes of all Member States participating in the SSM and in the SRM. On 30 November 2015 a sufficient number of Member States have ratified it, allowing full operationalisation of the SRF. As a result, the SRM and SRF entered into force on 1 January 2016.

The adoption of the IGA concerning the SRF implies an important question, somewhat contradictory, about the future of decision-making procedures.

SRF IGA is the last international agreement adopting measures in response to the EU financial crisis, after the Fiscal Compact Treaty and the European Stability Mechanism Treaty ${ }^{48}$. While the latter concern Member States' balance-sheets or the employment of public funds, the former regards private financial resources. Thus, one can observe that there is a new general trend in EU decision-making in the economic and monetary field, favouring the intergovernmental method for coordinated action in the spirit of solidarity rather than the community method ${ }^{49}$. Particularly, this new trend involves the private sector. In other words, the decision on the transfer and mutualisation of private resources to the EU mechanism of resolution for banks has been taken outside the EU. Nevertheless, while the communitarian method empowers the European Commission to analyse national positions, including those of private operators, before determining the EU general interest, the intergovernmental one, taken outside the EU institutional framework, seeks to delineate the lowest common ground allowing Member States to attain unanimity more easily but involving the private sector to a lesser extent than that of the first hypothesis.

\section{THE PROTECTION OF THE RIGHT TO PROPERTY IN RESOLUTION FOR BANKS}

The involvement of the private sector in resolution for banks must also be examined in the light of the fundamental right to property whose protec-

47 Agreement on the Transfer and Mutualisation of Contributions to the Single Resolution Fund (SRF IGA), signed on 14 May 2014.

48 Supra, para. 1.

49 Philippe DE SCHOUTHEETE, Decision-making in the Union, Notre Europe Policy Brief, 2011, n. 24, available at: http://www.institutdelors.eu/media/bref24-deschoutheete-en.pdf.pdf=ok, 4 . 
tion, in EU law, can be found in the TFEU as well as in the Charter of Fundamental Rights (Charter).

As stated in art. 345 TFEU: "The Treaties shall in no way prejudice the rules in Member States governing the system of property ownership».

In resolution for banks, private investors are submitted to an intervention of public authorities - throughout the bail-in - comparable to forms of ownership whose configuration, under that provision, must be made by the Member States. Thus, it could be argued that the existing system of property in them cannot be reduced to the duality between public and private entity. It must be extended to measures which, through their application, allow public authorities to contribute to the configuration of the national economic system. However, property regimes existing within the Member States cannot be subtracted from the fundamental principles of the TFEU.

Art. 345 TFEU embeds the principle of neutrality, under which the Treaty is indifferent as to whether a bank is held in public or private ownership. It limits, without preventing, the application of the Treaty as a whole to the way in which rules of a Member State deal with the right of ownership of undertaking. It could be affirmed that, with this provision, property law is exempted from influence of EU law and is exclusively for the Member States to regulate. However, one must observe that this norm does not prevent the EU from legislating on the matter since there is a fundamental distinction to be made: that between the existence of property rights and their exercise. The former remains untouched by the Treaty since Member States can legislate in the area of property law under EU law. In the exercise of this freedom as well as with regard to the exercise of the property rights so created, the EU provisions apply. The result of this is the "existence versus exercise» dichotomy ${ }^{50}$. Dealing with resolution of banks seems to answer to this dichotomy, as it concerns the exercise of property rights rather than their existence, which applies in general. On the one hand, art. 345 TFEU is neutral to the existence, i.e. the ownership, whether private or public, of a bank. On the other hand, particular decisions concerning the latter and involving the private sector, i.e. the write-down or conversion powers in relation to its liabilities, may be taken by public authorities.

Art. 17, para. 1, Charter states: «Everyone has the right to own, use, dispose of and bequeath his or her lawfully acquired possessions. No one may be deprived of his or her possessions, except in the public interest and in the cases

50 Bram AKKERMANS and Eveline RAMAEKERS, «Article 345 TFEU (ex Article 295 EC), Its Meanings and Interpretations», European Law Journal, vol. 16, no. 3, 2010, pp. 292-314, pp. 310-311. 
and under the conditions provided for by law, subject to fair compensation being paid in good time for their loss. The use of property may be regulated by law in so far as is necessary for the general interest».

The protection of the right to property given by this rule is very broad, due to the extensive interpretation of the word "possessions» ${ }^{51}$. This regards both the subjective right to ownership as well as the institution of ownership ${ }^{52}$. Furthermore, one must observe that, according to art. 31, para. 2, BRRD and art. 14, para. 2, Regulation num. 806/2014, resolution for banks is aimed at preserving financial stability and protecting public resources. These two objectives may be considered as legitimate purposes within the public interest justifying the involvement of the private sector in the operation in question. In this hypothesis, their achievement must be proportionate under two profiles. The first concerns the provision of the rules to attain them. The second regards the application of the same rules in the single resolution case ${ }^{53}$.

Finally, within the ambit of proportionality, one must observe that art. 34, para. 1, lit. g, BRRD and 15, para. 1, lit. g, Regulation num. 806/2014, provide the so-called «no creditor worse off principle» ${ }^{54}$. This has been introduced through the Banking Communication ${ }^{55}$. According to it, no creditor of a bank under resolution shall incur greater losses than would have been incurred if the same bank had been wound up under normal insolvency proceedings. In other words, shareholders and creditors of the bank concerned, if involved in its resolution, are treated in the same way as they would be under the normal insolvency proceedings ${ }^{56}$. It stems from the general principle of equal treatment. The latter requires that comparable situations must not be treated differently and that different situations must not be treated in the same way unless such treatment is objectively justified. The equivalence of different situations must be evaluated with regard to all their characteristic

51 See, Ferdinand WOLLENSCHLÄGER, «Art. 17 (1)», in Steve PEERS, Tamara HERVEY, Jeff KENNER and Angela WARD (eds.), The EU Charter of Fundamental Rights, A Commentary, Hart Publishing, Oxford, 2014, pp. 465-488, p. 465.

52 Sjef VAN ERP, «European and National Property Law: Osmosis or Growing Antagonism?», Maastricht University Faculty of Law Working Paper, 2006, available at: http:// www.iuscommune.eu/html/pdf/wvg/wvg6.pdf, 6.

53 WOJCIK, op. cit., p. 120.

54 John ARMOUR and Paul DAVIES, Principles of Financial Regulation, Oxford University Press, Oxford, 2016, p. 351.

55 Banking Communication, op. cit., para. 46.

56 Phoebus ATHANASSIOU, «Valuation in Resolution and the 'No Creditor Worse Off Principle'», Butterworths Journal of International Banking and Financial Law, vol. 29, 2014, pp. 16-21. 
features which must be identified and analysed in the light of the subject-matter and purpose of the EU act making the distinction at issue ${ }^{57}$.

On the basis of the «no creditor worse off principle», shareholders and creditors who suffer such greater losses are entitled to a compensation which would be equivalent to the shortfall they have suffered. The latter must be equivalent to the amount that shareholders and creditors would, in the end, have recovered if the bank had been subjected to normal insolvency proceedings. Within this ambit one must also observe the problem of calculating the amount of the compensation. Indeed, shareholders and creditors of a bank under resolution may challenge it with the aim to minimise the suffered losses. They may do that since many questions — under the technical profilethat would need to be dealt with in attempting to substantially determine the amount at issue have not been regulated by EU law and remain controversial and unclear ${ }^{58}$. Even recent case law, although confirming the general approach on the principles at issue, does not reason on the amount of the compensation and leaves the question open ${ }^{59}$.

\section{THE COURT'S APPROACH}

The analysis of the involvement of the private sector in resolution for banks has recently been the subject of a judgment of the Court of Justice ${ }^{60}$. The request for a preliminary ruling has been made in proceedings for review of the constitutionality of certain provisions of the Slovenian law on the banking sector which provide for exceptional measures designed to ensure the recovery of the banking system. Particularly, it concerns the validity and interpretation of certain points of the Banking Communication ${ }^{61}$ and

57 Judgment of the Tribunal in Accorinti and Others v EBC, T-79/13, EU:T:2015:756, para. 87; Judgment of the Tribunal in Nausicaa Anadyomène SAS and Banque d'escompte v EBC, T-749/15, EU:T:2017:21, para. 110.

58 Victor DE SERIËRE and Daphne VAN DER HOUWEN, «No Creditor Worse Off in Case of Bank Resolution: Food for Litigation?», Journal of International Banking Law and Regulation, 2016, p. 376-384, p. 376.

59 Nausicaa, paras 102-107-108-110-111-114-116-118.

60 Judgment of the Court in Tadej Kotnik and Others v Državni zbor Republike Slovenije, C-526/14, EU:C:2016:570.

61 Supra n. 19. 
the interpretation of certain arts. of Directive 2012/30/EU ${ }^{62}$ and Directive $2001 / 24 / \mathrm{EC}^{63}$.

After the recent financial crisis $^{64}$, the Bank of Slovenia determined that some banks under its prudential supervision were showing capital shortfalls and did not have sufficient assets to satisfy their creditors and to cover the value of deposits. As a result, it adopted decisions putting in place exceptional measures to effect, as the case may be, the recapitalisation, the rescue or the winding up of the banks concerned.

These measures, which were adopted on the basis of the national law on the banking sector, included the so-called subordinated rights. The latter - which consist in writing off equity capital, as well as hybrid capital and subordinated debt - share certain characteristics with debt products and certain characteristics with shares in equity capital. In case of insolvency of the bank concerned, their holders are paid after those of ordinary debentures but before shareholders. In exchange for their financial risk they offer a higher rate of return.

A number of questions concerning the measures at issue were referred to the Court of Justice. In particular, it was required to determine whether the Banking Communication - in so far as it lays down a condition of burden-sharing by shareholders and subordinated creditors as a prerequisite to the authorisation of State aid - must be interpreted as infringing arts. 107109 TFEU as well as the right to property.

Furthermore, it was asked to evaluate whether the measures for conversion of subordinated rights or write-down of the principal thereof represent a necessary and sufficient condition for State aid falling within the scope of the Banking Communication to be declared compatible with the internal market or whether it is sufficient, for that aid to be authorised, that the subordinated rights are converted or written down in a proportionate manner.

62 Directive 2012/30/EU of the European Parliament and of the Council of 25 October 2012 on coordination of safeguards which, for the protection of the interests of members and others, are required by Member States of companies within the meaning of the second paragraph of Article 54 of the Treaty on the Functioning of the European Union, in respect of the formation of public limited liability companies and the maintenance and alteration of their capital, with a view to making such safeguards equivalent (OJ L 315, 14.11.2012, p. 74).

63 Directive 2001/24/EC of the European Parliament and of the Council of 4 April 2001 on the reorganisation and winding up of credit institutions (OJ L 125, 5.5.2001, p. 15).

64 Supra, para. 1. 
In its examination the Court of Justice points out a relationship between the involvement of the private sector in resolution for banks - throughout the burden sharing and the bail-in — and State aid rules.

Firstly, it recalls that the Banking Communication was adopted on the basis of art. 107, para. 3 (b) TFEU ${ }^{65}$. According to this rule, the European Commission may consider to be compatible with the internal market aids that are configured «to remedy a serious disturbance in the economy of a Member State» and is entitled to refuse those not inducing the recipient undertakings to adopt conduct likely to assist attainment of one of the objectives referred to in the same rule ${ }^{66}$. As a result, the Court, according to settled case-law, states that aids improving the financial situation of the receiver enterprise, but not necessary for the achievement of the objectives specified in the rule in question, cannot be considered compatible with the internal market ${ }^{67}$.

It also finds that banks are often interconnected and that larger ones, in general, operate internationally ${ }^{68}$. Conforming to doctrine, it affirms that the failure of one or more credit institutions, due to the above-mentioned contagion effect ${ }^{69}$, is liable to spread rapidly to other financial operators, either in the Member State concerned or in other Member States ${ }^{70}$. This could lead, in its turn, to negative spill-over effects in other sectors of the economy.

In accordance to Advocate General Wahl ${ }^{71}$, it considers that the adoption of the Banking Communication on the basis of art. 107, para. 3 (b) TFEU is amply justified by the fact that, in the context of the recent global financial crisis, the economic systems of several Member States were affected by serious disturbances ${ }^{72}$.

The Communication's aim is to spell out the conditions for access to State aid designed to provide sustain to credit institutions of Member States and the requirements which that aid must satisfy if it is to be found compat-

\footnotetext{
65 Kotnik, para. 47.

66 IANUS and ORZAN, op. cit., pp. 240-241.

67 See, for example, judgment of the Court in HGA and Others v. Commission, C-630633/11P, EU:C:2013:387, para. 104.

68 Kotnik, para. 50.

69 Supra, para. 3.

70 Christoph OHLER, «International Regulation and Supervision of Financial Market After the Crisis», in Christoph HERMANN and Jörg Philipp TERHECHTE, European Yearbook of International Economic Law, Springer, Heidelberg, 2010, pp. 3-29, p. 18.

71 Opinion of Advocate General Wahl in Kotnik, C-526/14, EU:C:2016:102, point 56.

72 Kotnik, para. 51.
} 
ible with the internal market. Among these requirements one must observe the condition of burden-sharing. As a result, a precise role of the private sector in the resolution of banks is established in order that State aid should be limited to the minimum necessary and that any distortions of competition in the internal market should be limited ${ }^{73}$. Indeed, on the one hand, such burden-sharing measures can be understood as being adopted to prevent recourse to State aid merely as a tool to overcome the financial difficulties of the credit institution concerned. On the other hand, they are provided to ensure that, prior to the grant of any State aid, the banks which show a capital shortfall take steps, with their investors, to reduce that shortfall, in particular by raising equity capital and by obtaining a contribution from subordinated creditors. In other words, they limit the amount of the State aid granted ${ }^{74}$.

The Court finds that credit institutions whose shareholders and subordinated creditors had not contributed to the reduction of the capital shortfall would receive greater State aid than that which would have been sufficient to overcome the residual capital shortfall. As a result, there would be an infringement of EU competition rules applying to States ${ }^{75}$.

Finally, it affirms that the involvement of the private sector in resolution of banks would contribute to overcoming the above-mentioned problem of «moral hazard $»^{76}$. Indeed, it would ensure that credit institutions are not encouraged by the possibility of obtaining State aid to have recourse to financial instruments that carry greater risk and are more likely to cause significant losses, implying serious distortions of competition in the internal market ${ }^{77}$.

In the light of the foregoing considerations, the Court affirms that burden-sharing measures do not infringe the EU State aid rules.

With regard to the right to property, the Court reasons its judgment on the basis of art. 17, para. 1 of the Charter ${ }^{78}$, recalling that the Banking Communication is not capable of imposing an obligation on Member States to adopt burden-sharing measures involving, in resolution of banks, the private sector $^{79}$. However, the latter has to contribute, appropriately, to the costs of restructuring in order to limit to the minimum necessary the public sustain ${ }^{80}$.

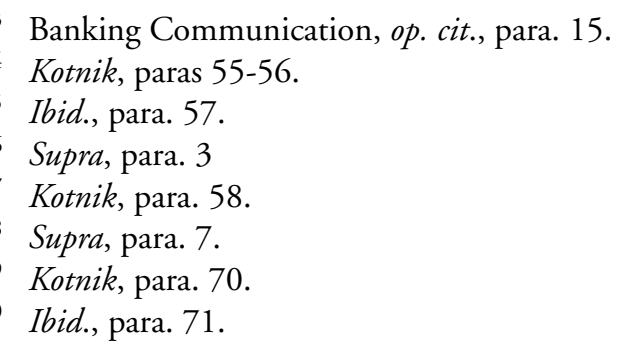


The Court affirms that burden-sharing measures cannot be considered as interference with the right to property of both the shareholders and the subordinated creditors of a bank under resolution ${ }^{81}$.

With reference to the former one must observe that, in general terms, they are liable for the debts of the credit institution up to the amount of its share capital. Therefore, their contribution -in order to overcome a bank's capital shortfall, prior to the grant of State aid - to the absorption of the losses suffered by that bank should have the same extent as if there were no State aid. In other words, the scale of their losses, regardless of the origin of the latter - a court insolvency order because no State aid is granted or a procedure for the granting of State aid which is subject to the prerequisite of burden-sharing - is, in any event, the same. As a result, these measures cannot be challenged for alleged infringement of the right in question ${ }^{82}$.

With regard to the subordinated creditors, the Court finds that invoking the "no creditor worse off principle» ${ }^{83}$, they should not receive less, in economic terms, than what their rights would have been worth under normal insolvency proceedings ${ }^{84}$. As a result, the burden-sharing measures on which the grant of State aid in favour of a bank under resolution cannot cause any detriment to the right to property of subordinated creditors ${ }^{85}$.

In its judgment, the Court makes the assessment of proportionality of the burden-sharing measures. It states that, in the event that a credit institution does not meet the minimum capital requirements - i.e. its capital is not sufficient to absorb its losses - subordinated rights must be converted, or the principal thereof must be written down, as a general rule, before the grant of State aid to that credit institution. The latter, in fact, under normal operating conditions, must be able to absorb any losses using only its resources and restoring its balance position independently ${ }^{86}$. As a result, public sustain must not be granted before its own capital and subordinate rights have fully contributed to offset its eventual losses. In other words, it must become a tool of last resort to assure the long-term viability of its recipient ${ }^{87}$. Furthermore, it must mandatorily coincide with the spread between the financial resources

\footnotetext{
Ibid., para. 72 .

Ibid., paras 74-75.

Supra, para. 6.

Kotnik, para. 77.

Ibid., para. 78.

Matthias HAENTJENS and Pierre DE GIOIA-CARABELLESE, European Banking and Financial Law, Routledge, London-New York, 2015, p. 111.

87 IANUS and ORZAN, op. cit., p. 279.
} 
necessary for the restructuring of credit institution and those found through the burden-sharing.

The aim is to circumscribe the banking crisis to the private sector, involving the public one only in situations whose gravity would affect the overall stability of the financial system both of the Member State concerned and of the EU as a whole.

Finally, the Court affirms that Member States are not compelled to impose on credit institution in distress, prior to the grant of any State aid, an obligation to convert subordinated rights into equity or to effect a writedown of the principal thereof, or an obligation to ensure that those rights contribute fully to the absorption of losses. Some exceptions, either partially, to burden-sharing measures may be made where the implementation of the latter «would endanger financial stability or lead to disproportionate results». Moreover, the conversion, or write-down, of a part of the subordinate rights is also admitted if it is sufficient to overcome the capital shortfall of the bank concerned.

\section{CONCLUSION}

The recent financial crisis in the Euro area has shown a close and negative relationship between sovereign risk and bank risk, having totally distorting effects on the internal market. The EU, to limit these effects intervened with many measures. One of them is the establishment of a resolution regime for banks under distress, based on the involvement of the private sector before granting any kind of public support to credit institutions.

This regime provides four types of resolution tools. The most important is the bail-in which is conceived to recapitalise a bank under resolution to the extent necessary to restore its ability to comply with its authorisation conditions and to continue carrying out its activities as well as to sustain sufficient market confidence in the same bank.

It must be noted that bail-in has some limits. Firstly, it tends to progressively restrict the freedom of action of banks in the financial market - with the increase of their exposure to the risk of default - and not always represent the appropriate deterrent for nonrigorous financial operations. Secondly, its effects on the cost of the funding raises are concentrated, for the most part, on the weaker banks increasing the financial market fragmentation. As a result, in some circumstances, its application may lead to opposite results to those expected.

Not all of the liabilities of a credit institution are subjected to the bail-in. Some of them are mandatorily excluded since they are protected in normal insol- 
vency proceedings or for reasons of continuity of business operations. The most important result of their exclusion is, surprisingly, the improvement of the autonomous and voluntary involvement of the private sector in resolution for banks.

In conclusion, it should be affirmed that the application of bail-in in relation to specific liabilities as well as its exclusion for other ones leads to controversial and, in some circumstances, contradictory effects.

The SRF is also based on the involvement of the private sector in resolution for banks. Although it has been established within the EU -i.e. with the communitarian method-arrangements regarding the transfer to and the mutualisation of contributions to it have been defined in an international agreement (IGA) — with the intergovernmental method. This implies an important question, somewhat contradictory, about the future of decision-making procedures-. While the former empowers the EU institutions to analyse national positions, including those of private operators, before determining the EU general interest, the latter seeks to delineate the lowest Member States common ground, involving the private sector to a lesser extent.

The involvement of the private sector in resolution for banks must also be examined in the light of the «no creditor worse off principle» stemming from the general principle of equal treatment. According to it, no creditor of a bank under resolution shall incur greater losses than would have been incurred if the same bank had been wound up under normal insolvency proceedings. Those sustaining such greater losses are entitled to a compensation which is equivalent to the suffered shortfall. The methods of calculation of this compensation have not been regulated by EU law and remain controversial and unclear. Even recent case law, although confirming the general approach of the principles at issue does not reason on the amount of the compensation and leaves the question open.

The Court has recently examined the involvement of the private sector in resolution for banks with particular regard to the EU competition rules applying to States. It has affirmed that this must not cause any detriment to the "no creditor worse off» principle and must not exceed what is necessary to overcome the capital shortfall of the credit institution concerned.

In conclusion, one can affirm that the involvement of the private sector in resolution for banks, if imposed in compliance with the right to property, the principle of equal treatment as well as that of proportionality, is compatible with EU law. Furthermore, Member States are not forced to involve it to contribute to the rescue of the bank under resolution prior to granting State aid. However, they take the risk that there will be a decision by the European Commission declaring the same aid to be incompatible with the internal market and compelling them to the involvement at issue in order to preserve EU financial stability. 